\title{
Erratum to: Achievement or Arrest? The Influence of the Collegiate Religious and Spiritual Climate on Students' Worldview Commitment
}

\author{
Matthew J. Mayhew • Alyssa Bryant Rockenbach
}

Published online: 9 May 2012

(C) Springer Science+Business Media, LLC 2012

\section{Erratum to: Res High Educ \\ DOI 10.1007/s11162-012-9262-7}

The second author "Alyssa Bryant Rockenbach" was incorrectly identified as "Alyssa $\mathrm{N}$. Bryant" in the original publication of the article.

The authors are correct as displayed above.

Springer regrets the error.

The online version of the original article can be found under doi:10.1007/s11162-012-9262-7.

M. J. Mayhew ( $\bowtie)$

New York University, 82 Washington Square East, 6th Floor, New York, NY 10003, USA e-mail: matt.mayhew@nyu.edu 